\section{Response to: 'Effectiveness and safety of tocilizumab for the treatment of refractory systemic sclerosis associated interstitial lung disease: a case series' by Narváez}

We read the intriguing findings by Narváez ${ }^{1}$ about the effect of tocilizumab (TCZ) in patients with established systemic sclerosis-associated interstitial lung disease (SSc-ILD) with great interest. In the double-blind, randomised, placebo-controlled faSScinate study ${ }^{2}$ and open-label extension, ${ }^{3}$ we assessed the efficacy and safety of TCZ in patients with systemic sclerosis. There were important differences between our trial and the data presented by Narváez ${ }^{1}$. In the faSScinate study, the patient population shown to benefit from TCZ had shorter duration of disease (mean disease duration of 1.6 years in faSScinate vs 6.9 years in Narváez), increased serum acute phase reactants, progressive skin disease and low normal mean forced vital capacity (FVC) levels (mean FVC\% predicted of $81 \%$ ) at study baseline. Compared with patients receiving placebo, patients receiving TCZ appeared to stabilise their FVC, an exploratory endpoint, and thus preserved their lung function: the mean change from baseline for $\mathrm{FVC} \%$ predicted for placebo was $-6.3 \%$ (95\% CI -8.9 to 3.8$)$ and for TCZ was $-2.6 \%(-5.2$ to $-0.1)$ at week 48 , with a delta of $3.7 \%(0.1$ to 7.3$)$; the delta in absolute millilitres for FVC at week 48 was $120 \mathrm{~mL}(-23 \mathrm{~mL}$, $262 \mathrm{~mL}$ ). These data are consistent with the findings from De Lauretis et $a l,{ }^{4}$ in which serum interleukin-6 levels appeared to be predictive of disease progression and/or death in patients with mild ILD (defined as FVC\% $>70 \%$ ). The effect of TCZ on the lung has been speculated to be related to modulating the activity of M2 macrophages. ${ }^{2}$ In contrast, Narváez ${ }^{1}$ is studying TCZ as a rescue treatment in patients with SSc with established ILD who have failed rituximab (RTX) in all cases and cyclophosphamide in $67 \%$ of cases. All patients were on ongoing mycophenolate mofetil while receiving TCZ, with follow-up after first TCZ dose ranging from 6 to 34 months. TCZ may have contributed to the stabilisation of lung function in a more severe and resistant ILD, which is notable given patients' previous immunotherapy failures. It is interesting to note that all four patients who appeared to have responded to TCZ had pretreatment FVC\% predicted of greater than $77 \%$ (mean $\mathrm{FVC} \%$ was $84.8 \%$ ). For patient 6 , whose pretreatment $\mathrm{FVC} \%$ was 108\%, it is unclear if the decline in diffusing capacity for carbon monoxide (DLCO)\% predicted represents worsening ILD or concomitant pulmonary vascular disease, especially with normal FVC\% predicted (with no change over time) and an FVC to DLCO ratio of 1.56 , a risk factor for pulmonary vascular disease in SSc. ${ }^{5}$ Given these captivating case reports, controlled studies should be conducted to assess if indeed TCZ is having an effect in patients with severe established SSc lung disease.

\section{Dinesh Khanna, ${ }^{1}$ Angelika Jahreis, ${ }^{2}$ Celia J F Lin ${ }^{2}$}

${ }_{1}^{1}$ Division of Rheumatology, University of Michigan, Ann Arbor, Michigan, USA

${ }^{2}$ Product Development, Genentech, Inc, South San Francisco, California, USA

Correspondence to Dr Dinesh Khanna, Division of Rheumatology, University of Michigan, Ann Arbor, MI 48109, USA; khannad@med.umich.edu

Handling editor Josef S Smolen

Contributors All authors contributed equally to the article.

Funding The authors have not declared a specific grant for this research from any funding agency in the public, commercial or not-for-profit sectors.

Competing interests DK is a consultant for Genentech/Roche. CJFL and AJ are employed by Genentech.

Patient consent Not required.

Provenance and peer review Commissioned; internally peer reviewed.

(C) Author(s) (or their employer(s)) 2019. No commercial re-use. See rights and permissions. Published by BMJ.

\section{Check for updates}

To cite Khanna D, Jahreis A, Lin CJF. Ann Rheum Dis 2019;78:e124.

Received 28 September 2018

Revised 9 October 2018

Accepted 10 October 2018

Published Online First 23 October 2018

\section{S Linked}

https://doi.org/10.1136/annrheumdis-2018-214449

Ann Rheum Dis 2019;78:e124. doi:10.1136/annrheumdis-2018-214477

\section{REFERENCES}

1 Narváez J, LLuch J, Alegre Sancho JJ, et al. Effectiveness and safety of tocilizumab for the treatment of refractory systemic sclerosis associated interstitial lung disease: a case series. Ann Rheum Dis 2019;78:e123.

2 Khanna D, Denton CP, Jahreis A, et al. Safety and efficacy of subcutaneous tocilizumab in adults with systemic sclerosis (faSScinate): a phase 2, randomised, controlled trial. The Lancet 2016;387:2630-40.

3 Khanna D, Denton CP, Lin CJF, et al. Safety and efficacy of subcutaneous tocilizumab in systemic sclerosis: results from the open-label period of a phase II randomised controlled trial (faSScinate). Ann Rheum Dis 2018;77:212-20.

4 De Lauretis A, Sestini P, Pantelidis P, et al. Serum interleukin 6 is predictive of early functional decline and mortality in interstitial lung disease associated with systemic sclerosis. J Rheumatol 2013;40:435-46.

5 Coghlan JG, Denton CP, Grünig E, et al. Evidence-based detection of pulmonary arterial hypertension in systemic sclerosis: the DETECT study. Ann Rheum Dis 2014;73:1340-9. 